\title{
Drug used pattern by self-medication among the RT-PCR positive health workers in Dhaka city
}

\author{
Elora Sharmin ${ }^{1 *}$, Sharmin Begum ${ }^{2}$, Swarmita Afreen $^{3}$, Diana Islam ${ }^{4}$, Sheikh Foyez Ahmed ${ }^{4}$
}

${ }^{1}$ Department of Pharmacology, Bangabandhu Sheikh Mujib Medical University, Bangladesh

${ }^{2}$ Department of Dermatology, Bangabandhu Sheikh Mujib Medical University, Bangladesh

${ }^{3}$ Department of Pharmacology, Gonoshasthya Samaj Vittik Medical College, Bangladesh

${ }^{4}$ Department of Cardiology, Bangabandhu Sheikh Mujib Medical University, Bangladesh

Received: 25 June 2021

Revised: 01 August 2021

Accepted: 02 August 2021

*Correspondence:

Elora Sharmin,

Email: elora.sharmin.edu.bd

Copyright: (C) the author(s), publisher and licensee Medip Academy. This is an open-access article distributed under the terms of the Creative Commons Attribution Non-Commercial License, which permits unrestricted non-commercial use, distribution, and reproduction in any medium, provided the original work is properly cited.

\section{ABSTRACT}

Background: To date there is no effective treatment against COVID-19. Self-medication played one of the major modes of treatment among general population as well as the health workers during this pandemic. Studying the pattern of self-medication among the health care workers (HCWs) may indicate their knowledge and skills towards rational use of medicines. The aim of the study was to assess the pattern self-medication among the COVID-19 affected HCWs.

Methods: This cross-sectional survey assessed the pattern of drug used by self-medication among the health workers who were RT-PCR positive in context to Bangladesh.

Results: A total of $267 \mathrm{HCW}$ data were collected. Most of the HCWs were in middle age group between 31-40 years with the mean age of $32.2 \pm 5.2$. Doctors $(83.9 \%)$ enrolled five times more than the nurses (16.1\%). Most of the HCWs $(60.3 \%)$ commenced medications just after appearance of symptoms and $27.0 \%$ went for the RT-PCR testing. Only $3.7 \%$ went to health care facilities for treatment. More than sixty percent of the respondents took medication by themselves just after start the symptoms, 19 (33.7\%) took advised from the specialists and attended at health facilities $2.6 \%$. Most of the patients $(42.7 \%)$ used azithromycin as antimicrobial agent. Paracetamol was the most used drug among the participants $(78.65 \%$ ) followed by antihistamines $(67.79 \%)$. Average number of drugs used by patients $3.1 \%$ and percentage of antibiotics per patients $42.6 \%$.

Conclusions: The prescribing practice of antibiotics shows deviation from the standard recommendation. Awareness regarding essentials drug list should be needed.

Keywords: Self-medication, Health workers, Self-treatment, Drugs pattern

\section{INTRODUCTION}

Drugs are the main intervention mechanisms used for the treatment, diagnosis, mitigation and prevention of diseases. ${ }^{1}$ Therefore, rational way of drug use needs to be always in the forefront practice contrast to this, the use of drugs when no drug therapy is indicated, the use of the wrong drug for a specific condition requiring drug therapy, the use of drugs with doubtful or unproven efficacy, the use of drugs of uncertain safety status, failure to provide available, safe, and effective drugs, the use of correct drugs with incorrect administration, dosages, and duration, the use of unnecessarily expensive drugs is deemed as irrational use of drugs.

The act of self-prescription is common in many pieces of Bangladesh despite financial status and level of instruction. While this is undeniable, the frequency of 
self-drug is might be higher in the low or centre pay nations without talking with qualified wellbeing professionals. ${ }^{1}$ Although the WHO stressed that rational self-medication practice helps in the prevention and treatment of some minor pathological conditions at affordable cost, but otherwise, it may cause wastage of resources, resistance to pathogens and serious health hazards with adverse drug reactions and prolonged morbidity. ${ }^{2,3}$ In a developing country like Bangladesh, the practice of self-medication may provide an alternative for people as low-cost to avoid high cost of clinical services and many drugs dispensed over the counter (OTC) without prescription. $^{4}$

Currently, the world is struggling with COVID-19 pandemic, which has been declared a global public health emergency (WHO, 2020). ${ }^{5}$ The focus has shifted to combating the pandemic; thereby curtailing the strides made in other healthcare indicators. The current situation has been exacerbated by inadequacies in healthcare infrastructure, essential medical equipment in health facilities and inadequate health workforce. The combat against COVID-19 is still continuing in Bangladesh, with the highest incidence rate in Dhaka city. The available data by WHO revealed that the highest AR was observed to continue in the Dhaka $(2321.7 / 1,000,000)$ and was highest (9422.1/1,000,000) during April to June 2020.6-11 As, there is no approved cure for COVID-19 the aim of treatment was focused to manage and reduce symptoms until clinical recovery. Most people (around 80\%) are asymptomatic or mild infection that can be treated at home. As stated in the National Guideline on Case Management of COVID-19 in Bangladesh, there is no precise effective treatment for COVID-19, the mainstay of management is early diagnosis and supportive care of symptoms and optimum support for organ function in severe illness. No drug is yet recommended as chemoprophylaxis as there is no quality evidence of efficacy and safety in COVID-19. Hence, this study was planned to assess the drug use pattern which includes parameters such as the number of drugs prescribed per encounter which measures the degree of polypharmacy, to measure the level of two important but commonly overused antibiotics and to measure the degree to which practices confirm an implement of national drug policy.

\section{METHODS}

\section{Study design}

This cross-sectional prospective study was conducted among a total no of 267 health workers working in different hospitals in Dhaka city, from July 2020 to December 2020, Bangladesh who were RT-PCR positive. The positive result of RT-PCR was collected from the different health care facilities. A data collection questionnaire form was developed and collect the data by interviewing with the participant. The face to face interview was waived as because of pandemic situation. Data was collected over phone, email and google docs form from the participants. Study participants were selected using purposive sampling technique. All data in the ordinary prescribing indicator recording form were first analyzed manually and then using Microsoft excel 2007. In the statistical analysis, frequencies, averages/means, standard deviations and percentages were obtained.

\section{Selection criteria}

\section{Inclusion criteria}

Healthcare workers with following criterias were included- (a) RT-PCR positive for COVID-19 (doctors and nurse); (b) age- above 18 years; (c) sex both male and female HCWs; (d) HCWs who did not admit in hospital for COVID-19 treatment; and (e) given informed oral consent

\section{Exclusion criteria}

Unwilling to participate in the study were excluded.

\section{Prescribing indicators}

The WHO prescribing indicators were used in this study. The indicators were pretested, and slight modification was made because the drug was self-prescribed so that they could be used easily to provide accurate data. The final versions of the pretested indicators are described below.

The prescribing indicators that were measured included: (a) the average number of drugs prescribed per encounter was calculated to measure the degree of polypharmacy. It was calculated by dividing the total number of different drug products prescribed by the number of encounters surveyed. Combinations of drugs prescribed for one health problem were counted as one; (b) percentage of drugs prescribed by generic name is calculated to measure the tendency of prescribing by generic name. It was calculated by dividing the number of drugs prescribed by generic name by total number of drugs prescribed, multiplied by 100; (c) percentage of encounters in which an antibiotic was prescribed was calculated to measure the overall use of commonly overused and costly forms of drug therapy. It was calculated by dividing the number of patient encounters in which an antibiotic was prescribed by the total number of encounters surveyed, multiplied by 100 ; (d) percentage of encounters with an injection prescribed was calculated to measure the overall level use of commonly overused and costly forms of drug therapy. It was calculated by dividing the number of patient encounters in which an injection was prescribed by the total number of encounters surveyed, multiplied by 100 ; and (e) percentage of drugs prescribed from an essential drug list (EDL) was calculated to measure the degree to which practices conform to a national drug policy as indicated in the national drug list of Bangladesh. Percentage was calculated by dividing number of products 
prescribed which are in essential drug list by the total number of drugs prescribed, multiplied by 100 .

\section{Statistical methods}

Descriptive statistical analysis has been carried out in the present study. The statistical data analysis was done using SPSS software version 23.0 for Windows.

\section{Data collection}

Data was collected over phone, email and google docs form from the participants. A semi-structured open-ended questionnaire was developed according to our context and was used as a data collection tool to interview the selected patients and interview was taken by required interviewer by direct face-to-face or telephone interviews. The time duration of each interview will take 10-15 min face-to-face and 15-20 min over telephone. A recorder was used with the permission of the patients during the interview. The recorded interview was discarded after data analysis. Collected data was recorded into separate case record forms and was processed and analyzed.

\section{RESULTS}

Figure 1 shows the distribution of HCWs according to age. A total of 267 COVID-19 positive HCWs records were collected. Most of the HCWs were in middle age group between 31-40 years with the mean age of 32.2 \pm 5.2 and age ranged from 21 to 60 years.

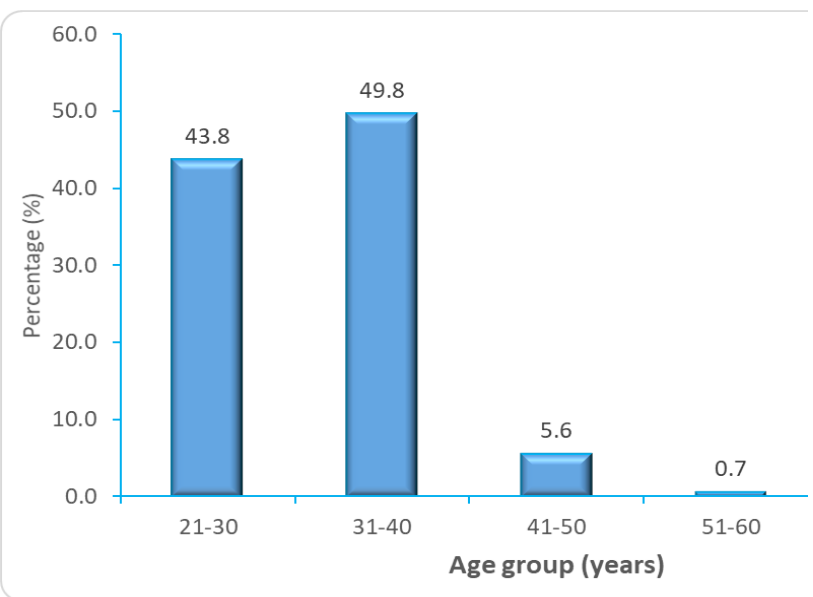

Figure 1: Distribution of the study participants according to age $(n=267)$.

Figure 2 depicts the distribution of $\mathrm{HCWs}$ according to gender. In this series, male HCWs $(62.2 \%)$ were affected more than the females $(37.8 \%)$ and the male and female ratio 2.3:1. Blue pie denotes male and yellow pie denotes female.

Table 1 shows the distribution of the respondent according to their occupation. Out of $267 \mathrm{HCWs}$, doctors $(83.9 \%)$ enrolled five times more than the nurses $(16.1 \%)$.

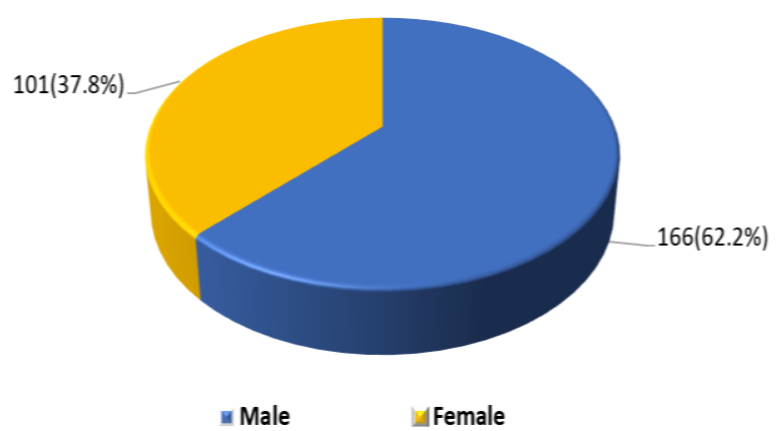

Figure 2: Distribution of the study participants according to gender $(n=267)$.

Table 1: Distribution of patients according to occupation $(n=267)$.

\begin{tabular}{|lll|}
\hline Occupations & Frequency & Percentage (\%) \\
\hline Doctor & 224 & 83.9 \\
\hline Nurse & 43 & 16.1 \\
\hline
\end{tabular}

Table 2 shows that most of the HCWs (60.3\%) commenced medications just after appearance of symptoms and $27.0 \%$ went for the RT-PCR testing. Only $3.7 \%$ went to health care facilities for treatment. Most of the patients were doctors and they could prescribe by themselves, and they had knowledge about treatment and drugs.

Table 2: Activities of the participants following appearance of the symptoms $(n=267)$.

\begin{tabular}{|lll|}
\hline $\begin{array}{l}\text { Activities following } \\
\text { symptoms } \\
\text { appearance }\end{array}$ & Frequency & Percentage $(\%)$ \\
\hline $\begin{array}{l}\text { Started drugs } \\
\text { Started non- } \\
\text { pharmacological } \\
\text { agents }\end{array}$ & 161 & 60.3 \\
\hline $\begin{array}{l}\text { Went to health } \\
\text { care facilities }\end{array}$ & 10 & 9.0 \\
\hline $\begin{array}{l}\text { Went for RT-PCR } \\
\text { testing }\end{array}$ & 72 & 3.7 \\
\hline
\end{tabular}

Table 3 shows that more than sixty percent of the respondents took medication by themselves. Others took advised from the specialists $(33.7 \%)$ or attended at health facilities $(2.6 \%)$.

Table 3: Distribution of patients according to the mode of seeking of drug treatment $(n=267)$.

\begin{tabular}{|lll|}
\hline Medications & Frequency & Percentage (\%) \\
\hline Self-medication & 169 & 63.3 \\
\hline $\begin{array}{l}\text { Advised by } \\
\text { specialist }\end{array}$ & 90 & 33.7 \\
\hline $\begin{array}{l}\text { Advised by } \\
\text { Hospital or clinic }\end{array}$ & 07 & 2.6 \\
\hline Others & 01 & 0.4 \\
\hline
\end{tabular}


Table 4 shows that more than ninety percent participants follow the national or international treatment guidelines. Most of the patients were doctors and they were aware the different treatment guidelines of COVID-19.

Table 4: Distribution of participants according to adherence of COVID-19 treatment guideline $(n=267)$.

\begin{tabular}{|lll|}
\hline Medications & Frequency & Percentage (\%) \\
\hline Yes & 253 & 94.8 \\
\hline No & 14 & 5.2 \\
\hline
\end{tabular}

Table 5 shows the pattern of pharmacological treatment. As antimicrobial agent, most of the patients (42.7\%) used azithromycin. In addition, ivermectin (23.60\%) and doxycycline were also used by the respondents. However, only 4 percent of respondents had used antiviral agents such as remdesivir and favipiravir. Paracetamol was the most used drug among the participants $(78.65 \%)$ followed by antihistamines $(67.79 \%)$. About half of the patients used vitamin D and zinc. As azithromycin was available drug and it has both antibacterial as well as antiviral activity and most of the patients were doctors and they had the knowledge regarding any drug.

Table 6 shows that the mean duration of pharmacological agent matched with standard treatment protocol. Mean \pm duration of azithromycin was $5.5 \pm 1.8$ and vitamin and minerals were $11.9 \pm 10.4$. Three fourth of the patients took antimicrobials and antipyretics. Two third of the patients took antihistamine and vitamin and minerals.

Table 7 shows that most of the patients $46.4 \%$ used 3 to 4 drugs. Approximately $34.1 \%$ of patients took more than 4 drugs. The mean \pm SD number of drugs per person was 4.14 \pm 1.67 . Table 8 shows average number of drugs prescribed or used per patients $3.1 \%$ and percentage of antibiotics per patients were $42.6 \%$.

Table 9 shows a total of 852 drug products were used by self-medication. Thus, the average number of drugs per prescription or mean was $3.1(\mathrm{SD}=0.31)$ with a range between 1 and 4 . The total number of drugs used by generic name was $10(3.7 \%)$. An antibiotic was used in 114 by self-medication (42.6\%), and an injection was prescribed after hospital admission in 118 encounters (44\%). Almost no drugs prescribed were on the essential drug list of Bangladesh.

Table 5: Distribution of the study participants by drug use pattern $(n=267)$.

\begin{tabular}{|lll|}
\hline $\begin{array}{l}\text { Pharmacological } \\
\text { treatment }\end{array}$ & Frequency & $\begin{array}{l}\text { Percentage } \\
(\%)\end{array}$ \\
\hline Azithromycin & 114 & 42.70 \\
\hline Doxycycline & 42 & 15.73 \\
\hline Hydroxychloroquine & 08 & 03.00 \\
\hline Ivermectin & 63 & 23.60 \\
\hline Oseltamivir & 01 & 0.37 \\
\hline Remdesivir & 03 & 1.12 \\
\hline Favirpiravir & 07 & 2.62 \\
\hline $\begin{array}{l}\text { Angiotensin } \\
\text { receptor blockers }\end{array}$ & 02 & 0.75 \\
\hline Corticosteroids & 04 & 1.50 \\
\hline Dexamethasone & 09 & 3.37 \\
\hline Methyl prednisolone & 03 & 1.12 \\
\hline Paracetamol & 210 & 78.65 \\
\hline Anti-coagulant & 40 & 14.98 \\
\hline Anti-histamine & 181 & 67.79 \\
\hline Cough expectorant & 28 & 10.49 \\
\hline O2 therapy & 02 & 0.75 \\
\hline $\begin{array}{l}\text { Others (vitamin D, } \\
\text { zinc) }\end{array}$ & 135 & 50.56 \\
\hline
\end{tabular}

Table 6: Distribution of the study participants by duration of drug use pattern $(n=267)$.

\begin{tabular}{|llll|}
\hline Pharmacological treatment & Frequency & Percentage (\%) & Duration (days \pm SD) \\
\hline Azithromycin & 114 & 42.70 & $5.5 \pm 1.8$ \\
\hline Doxycycline & 42 & 15.73 & $7.56 \pm 2.43$ \\
\hline Hydroxychloroquine & 63 & 23.60 & $2.08 \pm 1.52$ \\
\hline Ivermectin & 01 & 0.37 & 2.0 \\
\hline Oseltamivir & 03 & 1.12 & $5.7 \pm 1.15$ \\
\hline Remdesivir & 07 & 2.62 & $8.50 \pm 3.72$ \\
\hline Favirpiravir & 40 & 14.98 & $11.8 \pm 4.5$ \\
\hline Angiotensin receptor blockers & 4 & 1.50 & $5.0 \pm 1.2$ \\
\hline Corticosteroids & 03 & 1.12 & $8.75 \pm 3.5$ \\
\hline Dexamethasone & 210 & 78.65 & $3.4 \pm 1.69$ \\
\hline Methyl prednisolone & 181 & 67.79 & $7.8 \pm 8.86$ \\
\hline Paracetamol & 28 & 10.49 & $5.86 \pm 2.81$ \\
\hline Anti-coagulant & 02 & 0.75 & $6.0 \pm 1.14$ \\
\hline Anti-histamine & 135 & 50.56 & $11.9 \pm 10.4$ \\
\hline Cough expectorant & 114 & 42.70 & $5.5 \pm 1.8$ \\
\hline Oz therapy & 42 & 15.73 & $7.56 \pm 2.43$ \\
\hline Others (vitamin D, zinc) & 63 & 23.60 & $2.08 \pm 1.52$ \\
\hline
\end{tabular}


Table 7: distribution of participant according to number of drugs $(\mathrm{n}=\mathbf{2 6 7})$.

\begin{tabular}{|c|c|c|c|}
\hline Number of drugs & Number of patients & Percentage & Mean \pm SD \\
\hline One to two & 37 & 13.9 & \multirow{4}{*}{$4.14 \pm 1.67$} \\
\hline Three to four & 124 & 46.4 & \\
\hline Five to six & 91 & 34.1 & \\
\hline Seven and above & 15 & 5.6 & \\
\hline
\end{tabular}

Table 8: Average number of drugs used by self-medication and percentage of antibiotics used per patients.

\begin{tabular}{|lll|}
\hline Variables & Total drugs & Percentage (\%) \\
\hline Average number of drugs used by self-medication & 852 & 3.1 \\
\hline Percentage of antibiotics used per patients & 114 & 42.6 \\
\hline
\end{tabular}

Table 9: Assessment of prescribing indicators.

\begin{tabular}{|llll|}
\hline $\begin{array}{l}\text { Prescribing indicators assessed } \\
\text { Average number of drugs per } \\
\text { encounter }\end{array}$ & $\begin{array}{l}\text { Total drugs/ } \\
\text { encounters }\end{array}$ & Average/percent & $\begin{array}{l}\text { Standard derived or } \\
\text { ideal }\end{array}$ \\
\hline $\begin{array}{l}\text { Percentage of encounter with } \\
\text { antibiotics }\end{array}$ & 114 & 3.1 & $(1.0-1.8)$ \\
\hline $\begin{array}{l}\text { Percentage of encounters with } \\
\text { injection }\end{array}$ & 118 & $42.6 \%$ & $(20.0-22.8 \%)$ \\
\hline $\begin{array}{l}\text { Percentage of drugs prescribed by } \\
\text { generic }\end{array}$ & 10 & $44 \%$ & $(22 \%-24.1 \%)$ \\
\hline $\begin{array}{l}\text { Percentage of drugs from essential } \\
\text { drug list }\end{array}$ & 00 & $3.7 \%$ & $1.8-2 \%$ \\
\hline
\end{tabular}

\section{DISCUSSION}

To the best of our knowledge, this is the first study in Dhaka city evaluating the pattern of drug use in selfmedication practice among the health workers of prescription-only drugs in COVID-19 outbreak (April to June 2020) in Bangladesh ${ }^{12}$. As the survey population was doctors and nurses. In this series, Male HCWs (62.2\%) were affected more than the females $(37.8 \%)$ and the male and female ratio2.3:1, belonged to the age group of 21-60 years living in Dhaka city at the time of COVID-19 pandemic. As most of the patients were doctors and they could prescribe by themselves, and they had knowledge about treatment and drugs so most of them (60.3\%) commenced medications just after appearance of symptoms.

And $27.0 \%$ went for the RT-PCR testing. Only $3.7 \%$ went to health care facilities for treatment. Having selfmedication without detecting COVID-19 among a large number of respondents could also be due to feeling of insecurity influenced by availability of local medical resources, efficiency of public health system, and prevention and control measures taken in pandemic situation. ${ }^{13-15}$ The rate of self-medication of antimicrobial agents like azithromycin (54.15\%), doxycycline (40.25\%) were found much higher during the outbreak of COVID19 comparing to $21 \%$ and $25 \%$ for azithromycin and doxycycline before the pandemic as reported by Chowdhury et al. ${ }^{16}$ Azithromycin was the first highest percentage of people with self-medication throughout the previous years, whereas it became most common antibiotic during the present pandemic.

On the other hand, ivermectin being the anti-parasitic agent was self-medicated by $23.60 \%$ of the patients. This might be due to the nationwide broadcast of an experience by a team of Bangladeshi physicians and Bangladesh Medical College Hospital (BMCH) claimed as 'outstanding results' in 60 patients with COVID-19 patients all of whom recovered in combination of ivermectin and doxycycline. ${ }^{17}$ Though the drugs like chloroquine, hydroxychloroquine and azithromycin, was recommended in the treatment protocol of COVID-19 patients in Bangladesh, according to the "National Guidelines on Clinical Management of Coronavirus Disease-2019' published in the health directorate's website, hydroxychloroquine was used much less $(20.44 \%)$ than any other antimicrobials without prescription. ${ }^{18,19}$ This could be due to mass publicity and sharing of news in national and international news and social media as the drug can cause hazardous abnormalities in cardiac rhythm in COVID-19 patients, and should be limited only in clinical trials or hospitals with adequate facilities to monitor any cardiac complications, warned by FDA in a safety communication briefing globally. ${ }^{17}$

The overall the prevalence and dominance of selfmedication of antimicrobials in low- and middle-income 
countries were reported around $39 \%$ in previous studies before COVID-19 pandemic; but was outrageously higher $(88.33 \%)$ in Dhaka city during the pandemic..$^{20,21}$ Considering the knowledge and sources for medication more than sixty percent of the COVID positive health workers took medication by themselves. Others took advised from the specialists $(33.7 \%)$ or attended at health facilities $(2.6 \%)$. This finding was very much similar to the previous studies that reported the high prevalence of selfmedication (including antimicrobials) since people could obtain any drugs from the pharmacies without prescription even in the distant areas of the country. ${ }^{22}$

Having inappropriate antimicrobials and supplementary medications (zinc, calcium, vitamin D) without prescription is associated with the risk of drug interactions, masking symptoms of underlying diseases and most importantly, the development of antimicrobial resistance. ${ }^{23,24}$ A total of 852 drug products were used by self-medication. Thus, the average number of drugs per prescription or mean was $3.1(\mathrm{SD}=0.31)$ with a range between 1 and 4 . The total number of drugs used by generic name was $10(3.7 \%)$. An antibiotic was used in 114 by self-medication (58\%), and an injection was prescribed after hospital admission in 118 encounters (44\%). Almost no drugs prescribed were on the essential drug list of Bangladesh. This was not matched with any study because almost every study showed use of drugs from essential drug list. ${ }^{25}$ Although there is no specific treatment for COVID-19, the drug administration in Bangladesh started working in advance to increase the production of some supportive medicines. ${ }^{26}$

As far this was the first study among the healthcare professional who were COVID-19 positive in relation to self-medication in this pandemic situation. The limitation of this study was that it was a convenience sample which is inferior to probability sampling in its representativeness.

\section{CONCLUSION}

Most of the patients were doctors and they were aware the different treatment guidelines of COVID-19. Paracetamol was the most used drug among the participants and followed by antihistamines. As azithromycin was available drug and it has both antibacterial as well as antiviral activity. Most of the HCWs were not use drugs from essential drug list. Awareness regarding essential drug list and use will be needed.

\section{ACKNOWLEDGEMENTS}

Authors would like to extend deep gratitude to HCWs for helping by giving information and participate in this study willingly.

\section{Funding: No funding sources}

Conflict of interest: None declared

Ethical approval: The study was approved by the Institutional Ethics Committee

\section{REFERENCES}

1. Oyediran O, Ayandrian EO, Olatubi MI. Awareness of risk associated with self-medication among patients attending out-patient department of a tertiary hospital in south western Nigeria. Int $\mathbf{J}$ Africa Nursing Sci. 2019;10:110-5.

2. WHO. Report of the WHO Expert Committee on National Drug Policies. Geneva, Ed: 1, 1995. Available at: https://apps.who.int/iris/handle/ 10665/63068?locale-attribute=n\&showfull. Accessed on 13 June 2021.

3. Hughes CM, McElnay JC, Fleming GF. Benefits and risks of self-medication. Drg Saf. 2001;24:1027-37.

4. Hussain S, Malik F, Hameed A, Riaz H. Exploring health seeking behavior, medicine use and selfmedication in rural and urban Pakistan. Southern Med Rev. 2008;3:32-4.

5. Lai CC, Shih TP, Ko WC, Tang HJ, Hsueh PR. Severe acute respiratory syndrome coronavirus 2 (SARSCoV-2) and coronavirus disease-2019 (COVID-19): The epidemic and the challenges. Int $\mathrm{J}$ Antimicrob Agents. 2020;55(3):105924.

6. Holmes KV. SARS coronavirus: a new challenge for prevention and therapy. J Clin Invest. 2003;111(11):1605-9.

7. Holmes KV. SARS coronavirus: a new challenge for prevention and therapy. J Clin Invest. 2003;111(11):1605-9.

8. Bogren M, Erlandsson K, Johansson A, Kalid M, Igal A, Mohamed J, et al. Health workforce perspectives of barriers inhibiting the provision of quality care in Nepal and Somalia - A qualitative study. Sex Reprod Healthc. 2020;23:100481.

9. Kretchy, IA, Danso M, Kretchy JP. Medication management and adherence during the COVID-19 pandemic: Perspectives and experiences from low-and middle-income countries. Research in social \& administrative pharmacy. RSAP. 2021;17(1):2023-6.

10. Roberts T, Miguel EG, Krupchanka D, Shidhaye R, Patel V, Rathod S. Factors associated with health service utilisation for common mental disorders: a systematic review. BMC Psychiatry. 2018;18(1):262.

11. WHO. Coronavirus disease (COVID-2019) Bangladesh situation reports, 2021. Available at:https://www.who.int/docs/defaultsource/searo/ban gladesh/covid19whobangladeshsituationreports/whocovid-19-update1820200629. Accessed on 13 June 2021.

12. Disease Control Division, Directorate General of Health Services Ministry of Health \& Family Welfare; Government of the People's Republic of Bangladesh. National Guidelines on Clinical Management of Coronavirus Disease 2019 (Covid-19), by Version-4, 2020. Available at: https://dghs.gov.bd/index.php/ en/home/5343-covid-19-update. Accessed on 13 June 2021.

13. Baggio MA, Formaggio FM. Self-medication: showing self-carelessness by nursing professionals. Rev Enferm UERJ. 2009;17(2):224. 
14. Roberts T, Miguel EG, Krupchanka D, Shidhaye R, Patel V, Rathod S. Factors associated with health service utilisation for common mental disorders: a systematic review. BMC Psychiatry. 2018;18(1):262.

15. Wind TR, Komproe IH. The mechanisms that associate community social capital with post-disaster mental health: a multilevel model. Soc Sci Med. 2012;75(9):1715-20.

16. Chowdhury N, Islam MR, Hasan MM. Cephalosporin3G, Highly Prescribed Antibiotic to Outpatients in Rajshahi, Bangladesh: Prescription Errors, Carelessness, Irrational Uses are the Triggering Causes of Antibiotic Resistance. Int $\mathbf{J}$ Pharmacy Teaching Practices. 2013;4(1):504-10.

17. News Report. Available at: https://thelogicalindian. com/storyfeed/awareness/selfmedicationcoronaviruscovid-19-pandemic-20327. Accessed on 13 June 2021.

18. Caly L, Druce JD, Catton MG, Jans DA, Wagstaff KM. The FDA-approved drug ivermectin inhibits the replication of SARS-CoV-2 in vitro. Antiviral Res. 2020;178:104787.

19. National Guidelines on Clinical Management of Coronavirus Disease 2019 (COVID-19), by Disease Control Division, Directorate General of Health Services Ministry of Health and Family Welfare; Government of the People's Republic of Bangladesh Version-4. Available at: https://dghs.gov. bd/index.php/en/home/5343covid19update. Accessed on 13 June 2021.

20. Ocan M, Obuku EA, Bwanga F, Akena D, Richard S, Ogwal J, et al. Household antimicrobial selfmedication: a systematic review and meta-analysis of the burden, risk factors and outcomes in developing countries. BMC Public Health. 2015;15:742.
21. Morgan DJ, Okeke IN, Laxminarayan R, Perencevich EN, Weisenberg S. Non-prescription antimicrobial use worldwide: a systematic review. Lancet Infect Dis. 2011;11(9):692-701.

22. Islam MS. Self-medications among higher educated population in Bangladesh: an email based exploratory study. Internet J Health. 2007;5:2.

23. Okeke IN, Klugman KP, Bhutta ZA, Duse AG, Jenkins P, Brien TF, et al. Antimicrobial resistance in developing countries. Part II: strategies for containment. Lancet Infect Dis. 2005;5(9):568-80.

24. WHO. Community-Based Surveillance of Antimicrobial use and Resistance in Resource constrained settings. A report on five pilot projects, 2009. Available at: http//www.apps.who.int/ medicinedocsdocuments/s16168e.pdf. Accessed on 13 June 2021.

25. Desalegn AA. Assessment of drug use pattern using WHO prescribing indicators at Hawassa University Teaching and Referral Hospital, south Ethiopia: a cross-sectional study. BMC Health Serv Res. 2013;13:170

26. DGDA. Medicine supply, prices managed well amid crisis, 2020. Available at: https://www.thedaily star.net/frontpage/news/medicine-supply-pricesmanaged-well-amid-crisis. Accessed on 13 June 2021.

Cite this article as: Sharmin E, Begum S, Afreen S, Islam D, Ahmed SF. Drug used pattern by selfmedication among the RT-PCR positive health workers in Dhaka city. Int J Basic Clin Pharmacol 2021;10:1049-55. 